\title{
ROMA HUKUKU'NDA LAESIO ENORMIS VE KARŞILAŞTIRMALI HUKUK AÇISINDAN GABİN
}

\author{
Arş. Gör. Mehmet ÜÇER*
}

\section{GİRIŞ}

Karşı1ıklı (iki tarafa borç yükleyen) sözleşmelerde, tarafların edimleri arasında tam bir oran olması beklenemez. Taraflardan her biri, bir mal veya hizmeti, mümkün olan en düşük bedelle elde etme eğilimi içindedir. Ancak, edimler arasında açık bir oransızlık bulunması durumunda, hukuk düzeninin buna müdahale edip etmeyeceği veya müdahale edecekse ne oranda müdahale edeceği, o ülkenin ekonomik sistemi ile yakından ilgilidir ${ }^{1}$. Liberal sistemler, soruna sözleşme özgürlüğü çerçevesinde yaklaşır ve tarafların bu konudaki anlaşmalarına uyar ${ }^{2}$. Oysa sosyal adaleti esas alan ve güçlüye karşı zayıfı korumayı ilke olarak benimseyen hukuk sistemleri, olaya seyirci ve ilgisiz kalmak yerine müdahale yolunu seçerler.

Peki hukuk düzeni, hangi koşullarda sözleşme özgürlüğüne bu sebeple müdahale edecektir ve bu müdahalenin kapsamı ne olacaktır? Bir başka soru da şudur: Farklı hukuk sistemleri bu gibi durumlarda aynı refleksi mi göstermektedir? Daha açık bir anlatımla, değişik hukuk sistemlerinin konuya ilişkin yaklaşım ve çözüm tarzları arasında bir yeknesaklık var mıdır?

Bazı modern hukuk sistemleri, karşılıklı sözleşmelerde, ivazlar arasındaki büyük orandaki eşitsizliğin, bir taraf için çok büyük dezavantajlar yaratması durumunda, zarar gören tarafın zararının giderilmesi yönünde imkânlar tanımaktadır ${ }^{3}$. Bu eşitsizliğin neden olduğu zararlar, İskoç

\footnotetext{
Ankara Üniversitesi Sosyal Bilimler Enstitüsü Roma (Özel) Hukuku Bilim Dalı Araştırma Görevlisi

1 Schwarz, Andreas B. (Çev. Bülent Davran): Borçlar Hukuku Dersleri, I. Cilt, İstanbul, 1948, s. 346.

2 Umur, Ziya: Roma Hukuku Ders Notları, İstanbul, 1987, s. 358.

3 Watson, Alan: Roman Law\&Comparative Law, University Georgia Press, AtinaLondra, 1991, s. 201.
} 
Hukukunda enorm lesion olarak adlandırılmaktadır. İskoçlar tarafindan kullanılan bu terim, Roma hukukunun laesio enormis teriminden türetilmiştir ${ }^{4}$. Laesio enormis terimi ise, Roma hukukçularının bir adlandırması olmayıp, Ortaçağ commentator'ları tarafından, Iustinianus'un Codex'ine dayanılarak türetilmiştir ${ }^{5}$.

Şuna işaret etmek gerekir ki, farklı hukuk sistemlerinin kullandığ1 terimlerde ve çözüm yollarında farkl1lıklar olması doğaldır ve mevcut durum da bu yöndedir. Hatta aşağıda açıklayacağımız üzere, aynı kaynaktan beslenen hukuk sistemlerinde dahi bu farklılıkları görmekteyiz; örneğin, Roma hukuku kökeninden gelen Fransız, Alman ve Türk-İsviçre borçlar hukuklarında bu farklılık görülmektedir. Bu bakımdan, sorunun doğru bir şekilde ortaya konulmasında, kaynaklara inmek zarureti vardır.

Doktrinde, gabin konusunun, Türk hukuku bakımından çok detaylı bir şekilde ele alındığı çalışmalar mevcuttur. Biz, daha ziyade, Roma hukuku ve karşılaştırmalı hukuku temel alan bir çalışma yapmayı amaçlamaktayız. $\mathrm{Bu}$ sebeple, gabin konusunda, Türk-İsviçre hukukunu ele aldığımız başlıkta, yapılmış olan bu çalışmaların tekrarı niteliğinde olabilecek detaylı bir inceleme yerine, konunun anlaşılmasına imkân verecek düzeyde açıklamalar yapmakla yetineceğiz.

\section{ROMA HUKUKU'NDA LAESIO ENORMIS}

Roma hukuku dışındaki eski hukuklarda, gabin konusuna, yalnızca iki hukuk sisteminde yer verildiğini görmekteyiz. Bunlar Çin ve Yahudi hukuk sistemidir. Çin kanunlarında, zor kullanmak suretiyle, kanundışı faiz almak amacıyla güç kullanılması veya karşı tarafın adil olmayan koşullarla alım veya satıma zorlanması cezalandırılmıştı. Buna karşılık, Yahudi hukuku, genel katılığının aksine, bu konuda oransızlığın 1/6'yı aşmaması durumunda, işleme müsaade etmekteydi ${ }^{6}$.

Roma hukuku, ilk dönemlerinde ve klasik dönemde liberal bir yaklaşım izlemiş ve karşılıklı sözleşmelerde taraflar arasında belirlenen semenin gerçek değere uyması gibi bir koşul aramamıştı. En ucuz fiyata mal ve hizmet satın almak veya en pahalı fiyata satmak, bütün sözleşmelerde görülebilen, insan davranışlarının doğal bir eğilimidir. Postklasik döneme gelinceye kadar, Roma hukukunda, bu eğilimin sınırsız olarak tanınması düşüncesi vard1 ${ }^{7}$. Nitekim Paulus'a ait bir metinde, bu eğilim açıkça görülmektedir:

\footnotetext{
4 Watson, s. 201.

5 Thayer, J. B.: "Laesio Enormis", Kentucky Law Journal, (www.heinonline.org/HOL/Page?handle $=$ hein.journals $/$ kentlj25\&size $=2 \&$ collection $=$ jour nals\&id=331)'dan, s. 321.

6 Thayer, s. 321.

7 Schwarz, s. 346.
} 
Paulus D. 19.2.22.3: "Daha yüksek kıymeti olan bir şeyi daha aşağı bir semen mukabilinde almak ve daha az kıymeti olan şeyi daha pahalıya satmak ve bu suretle birbirini aldatmak, satım sahasinda tabiatiyle caiz olduğu gibi, bu hâl kiranın muhtelif nevileri sahasında da hukuka uygundur."

Oysa, Postklasik devirde, "devlet sosyalizmi” hakim olduğundan", fiyatları kontrol etmek gereği duyulmuş ve tarafların iradesine yönelik bir sınırlama getirilmiştir ${ }^{10}$. İmparator Diocletianus zamanında, birçok mal ve hatta işçi ücretleri için resmi tarifeler getirilmişti. Bunun temel amacı, fiyat yükselmelerini ve paranın değer kaybını önlemekti ${ }^{11}$.

$\mathrm{Bu}$ eğilim içinde laesio enormis denilen bir ilke oluşturulmuştu. $\mathrm{Bu}$ ilkenin oluşumu, özellikle satım sözleşmesinde alıcının borçlarını düzenleme konusunda karşılaşılan sorunlara dayanmaktadır ${ }^{12}$. M.S. 285 ve 293 yıllarına ait iki emirname (rescript $\left.{ }^{13}\right)$, laesio enormis için tek kanıt olarak kabul edilmektedir. Bunlar:

C.4.44.2: "Rem maioris pretii si tu vel pater tuus minoris pretii, distraxit, humanum est, ut vel pretium te restituente emptoribus fundum venditum recipias auctoritate intercedente iudicis, vel, si emptor elegerit, quod deest iusto pretio recipies. minus autem pretium esse videtur, si nec dimidia pars veri pretii soluta sit".

C.4.44.2: "Şayet sen veya baban, yüksek fiyatı olan bir şeyi düşük bir fiyatla satmışsan, alıcıya bedeli iade ettikten sonra, yargıcın müdahalesi yardımıyla, satmış olduğun çiftliği dava yoluyla geri almışsan veya alıcının seçimiyle semenin eksik olan kısmını almışsan bu adildir. Semen, eğer gerçek değerinin yarısı verilmemişse çok düşük farz edilir".

C.4.44.8: "Si voluntate tua fundum tuum filius tuus venumdedit, dolus ex calliditate atque insidiis emptoris argui debet vel metus mortis vel cruciatus corporis imminens detegi, ne habeatur rata venditio. hoc enim solum, quod paulo minori pretio fundum venumdatum significas, ad rescindendam emptionem invalidum est. quod videlicet si

\footnotetext{
Schwarz, s. 347.

Umur, s. 358.

10 Umur, s. 358; Rado, Türkan: Roma Hukuku Dersleri-Borçlar Hukuku, İstanbul, 1982, s. 119; Tahiroğlu, Bülent: Roma Borçlar Hukuku, İstanbul, 2000, s. 164-165; Küçükgüngör, Erkan / Emiroğlu, Haluk: "Roma Hukukunda ve Bazı Çağdaş Hukuk Düzenlerinde Laesio Enormis”, A.Ü.H.F.D., Cilt: 53, Sayı: 51, 2004, s. 80.

11 Umur, s. 358; Rado, s. 119; Tahiroğlu, s. 164.

12 Küçükgüngör/Emiroğlu, s. 77.

13 Rescriptum, özel şahısların yazılı olarak sordukları hukuki sorunlara ilişkin sorulara, imparatorun verdiği ve kanun hükmünde cevaplardır; Umur, Ziya: Roma Hukuku Lügatı, İstanbul, 1983, s. 186.
} 
contractus emptionis atque venditionis cogitasses substantiam et quod emptor viliori comparandi, venditor cariori distrahendi votum gerentes ad hunc contractum accedant vixque post multas contentiones, paulatim venditore de eo quod petierat detrahente, emptore autem huic quod obtulerat addente, ad certum consentiant pretium, profecto perspiceres neque bonam fidem, quae emptionis atque $v$ enditionis conventionem tuetur, pati neque ullam rationem concedere rescindi propter hoc consensu finitum contractum vel statim vel post pretii quantitatis disceptationem: nisi minus dimidia iusti pretii, quod fuerat tempore venditionis, datum est, electione iam emptori praestita servanda".

C.4.44.8: "Eğer oğlun senin talimatınla senin çiftliğini satarsa, satışın geçerli olarak kabul edilmemesi için, alıcının desise ve kurnazlığından olan hileyi veya ölüm korkusu veya vücudundaki yakın bir işkenceyi ispat etmesi gerekir. Sadece çiftliğin çok düşük bir semenle satılmış olduğunu göstermen, satımın iptaline yetmez. Açıkça, alım ve satım sözleşmesinin özünü düşünürsen, alıcının daha ucuza almak, satıcının daha pahalıya satmak umudu ile hareket ederek ve çok az bir tartışmayla satıcının çok az bir fiyat azaltmasıyla ve alıcının onun talep ettiğine biraz ilavesiyle semen konusunda anlaştıkları görülür; daha sonra gerçekten göreceksin ki, ne alım satım anlaşmasında korunan iyiniyetin ne de herhangi bir nedenin semen üzerinde s1k1 pazarlıklardan sonra üzerinde anlaşılan sözleşmenin kesinlikle iptal edilemeyecektir; meğerki alıcıya önceden seçim hakkı verildiğinde, semenin satım sırasında yarıdan daha az olduğu görülsün."14

Bu iki metin, tarih olarak çok yakın olduğu, hemen hemen aynı şeyleri ifade ettiği ve başkaca meşru bir kanıt da bulunmadığı için, laesio enormis'in tarihsel gelişimine ait tam ve kesin bir sonuca ulaşmak imkânı bulunmamaktadır. Belki en fazla söylenebilecek şey, bu metinlerle Digesta metinleri arasındaki aykırılıkların ne olduğudur. Klasik hukukçuların konuya yaklaşımına ilişkin bir şey de bilinmemektedir. $\mathrm{Bu}$ emirnamelerin bir interpolatio $^{15}$ olduğu ve Iustinianus dönemine ait olduğu iddia edildiğinden beri, sorun daha karmaşı hale gelmiştir ${ }^{16}$. Iustinianus'un derlemesi içinde çok küçük bir yer işgal etmesine rağmen, bu iki emirnamenin, sonsuz

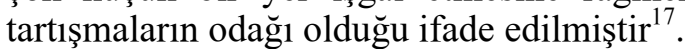

14 Her iki emirname metni Watson, s. 202'deki İngilizce metinden çevrilmiştir.

15 Iustinianus'un emriyle, Corpus Iuris Civilis'i derleyen hukukçuların, klasik hukukçulardan parçalar halinde aldıkları metinler ve imparator emirnamelerini zamanın koşullarına uydurmak ve uygulamasını temin etmek için yaptıkları değişikliklerdir; Umur, Lügat, s. 95.

16 Watson, s. 202-203.

17 Thayer, s. 322. 
$\mathrm{Bu}$ emirnamelerin interpolatio olduğ ${ }^{18}$ ve olmadığı yönünde çeşitli fikirler ileri sürülmüştür. Interpolatio lehinde olan görüşleri şu şekilde özetlemek mümkündür: Her şeyden önce, bu metinler, şayet sonradan bir değişikliğe maruz kalmamışsa açıklanamaz. Örneğin, C.4.44.2'de satıcı ilkin "sen ve baban" demesine rağmen, fiil sadece babaya ilişkindir. Fakat sonradan satıcı, "sen" demekte ve başlangıçta çoğuldan bahsedildiği halde, sonradan tekile inmektedir. Yine aynı şekilde, önce "bir şey"in satışından söz edildiği halde, sonradan "bir çiftlik" denmektedir. C. 4.44.8' de başvurulan "alıcıya önceden seçim hakkı verildiğinde" ifadesinin, tek başına emirnamede söylenmesi anlamsızdır. C. 4.44.2'deki kuralın özü de Diocletianus dönemi esas alınınca şüphe oluşturmaktadır. Eğer satıcı baba idiyse, babanın hayatta olduğu zaman başlanmamış bir davaya nasıl getirildiği açık değildir. Interpolatio olduğuna ilişkin ikinci argüman ise, varlığı çok iyi bilinen Codex Theodosianus'ta, laesio enormis kurumunun bilinmiyor oluşudur ${ }^{19}$.

Interpolatio'nun varlığını reddeden görüşün temel argümanlarını ise, şöyle özetlemek mümkündür: İlkin, özellikle C.4.44.2'de değişiklik olmadığını ifade etmek güç olsa da, bu değişikliklerin öze ilişkin olduğunu ifade etmekte güçlük vardır. Örneğin, çocuğun dava hakkına ilişkin bir şüphe, laesio enormis' in varlığını da tek başına şüpheli hale getirmez ve söz konusu şüphe genişletilemez. İkinci olarak, Diocletianus, ekonomik krizin bulunduğu bir dönemde hüküm sürmüş ve bu krizle, hukuk yoluyla mücadele etmiştir. Geniş bir mal ve hizmet alanında, azami fiyata ilişkin, M.S. 301 yılına ait ünlü beyannamesi, bu alanda ilk örnekti ve başarısızlığa uğramıştı. Onun "laesio enormis"e ilişkin başarısızlığa uğramış ve halefleri tarafından göz ardı edilmiş ilkeleri, Iustinianus tarafından ihya edilmiş olamaz mı? Üçüncü olarak, eğer Iustinianus bu önemli yeniliği getiren kişi ise, bunu kendi Constitutio'sunda yayımlardı. Hukuka ilişkin bu katkısını gizlemesinin hiçbir nedeni olamaz ${ }^{20}$.

Ağırlıklı görüş, bu emirnamelerin ve ilkelerin Iustinianus zamanına ait olduğu ve interpolatio olduğu şeklinde ise $\mathrm{de}^{21}$, yine de bu emirnamelerin Diocletianus veya Iustinianus zamanına ait olduğuna ilişkin kesin bir kanıt olarak da ortaya konulamayacağı doğrultusundadır. ${ }^{22}$.

İlkelerin kaynağına ilişkin, ortada bir bilgi eksikliği vardır. $\mathrm{Bu}$ bakımdan da, kısır bir döngü içinde olunduğu düşünülebilir; zira nedenler bilinmiyorsa, onun alanı da belirlenemez. Eğer alan bilinmiyorsa nedenleri

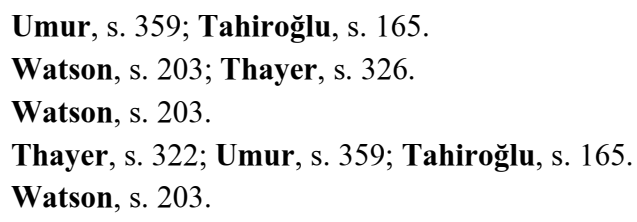


de keşfedilemez. Fakat gerçekte, bu bilgi eksikliği, bir yönüyle de faydalı olmuştur. Bu sayede, çok farklı tartışmalar olmuş ve kimi zaman geniş, kimi zaman da dar yorumlar yapılmıştır. Bunlar hukukun gelişimine katkı sağlamıştır. Örneğin Hugo Grotius, soyut ahlak temelli yaklaşımlar sergilemesine karşın; Jacques Cujas ekonomik ihtiyaç ile ilgili yorumlar yapmıştır. ${ }^{23}$ Zaten, genel olarak gözlemlenen husus, gerek tartışmaların, gerekse çözüm önerilerinin ilgililerin sosyal ve politik görüşlerindeki farklılı̆̆ 1 yansıtmış olduğudur. Bu konudaki son eğilimler, Iustinianus'un emirnamelerde interpolatio yaptığı şeklindedir; zira yapılan tüm incelemeler şu gerçeğe işaret etmektedir: Diocletianus, bu gibi işlemlerin iptaline izin vermişti; fakat Iustinianus, bunun için gerekli olan koşulları ve kapsamı değiştirmişti ${ }^{24}$.

Bütün bu tartışmaları bir yana bırakarak, sonuçta laesio enormis' in 16 ve 17. yüzyıllarda, sözleşmeler hukuku teorisinin köşe taş1 olan sözleşme özgürlüğ̈̈ ile birbirine zit olduğunu görmekteyiz ${ }^{25}$. THOMAS, sözleşme özgürlüğü gibi, laesio enormis'in de ideolojik bir yönü olduğunu ifade etmektedir. Özgürlüğün ve serbestliğin hukuk ilkelerinin temel değeri olduğuna ilişkin koşullandırmalar sebebiyle, hukukçu nesillerinin uzunca bir dönem, laesio enormis'i kabul edilemez bir hata olarak gördüklerini, fakat bu hukukçuların sözleşme özgürlüğünün 1770-1870 yılları arasındaki endüstriyel kapitalizm ile siyam ikizleri gibi olduğu konusunda bilgilendirilmemiş olmasından kaynaklandığını ifade etmektedir ${ }^{26}$.

Şunu da önemle belirtmek gerekir ki, laesio enormis kurumu, sözleşmenin yapıldığı sırada var olan koşullar dikkate alındığında uygulama alanı bulur. Yoksa sözleşmede, karşılıklı edimler belirlendikten sonra ortaya çıkan ve edimlerden birinin aşırı oranda değer kazanması veya yitirmesi durumunda; artık laesio enormis değil, clausaula rebuc sic stantibus veya dürüstlük kuralı uygulama alanı bulur ${ }^{27}$.

\section{BAZI ÇAĞDAŞ HUKUK DÜZENLERINNDE GABİN}

Yukarıda işaret ettiğimiz üzere, modern Fransız, Alman ve Türkİsviçre hukukları Roma hukukunun etkileri ile şekillenmişlerdir. Buna rağmen, özellikle gabin konusunda, saydığımız bu hukuk sistemleri arasında farkl11ıklar mevcuttur.

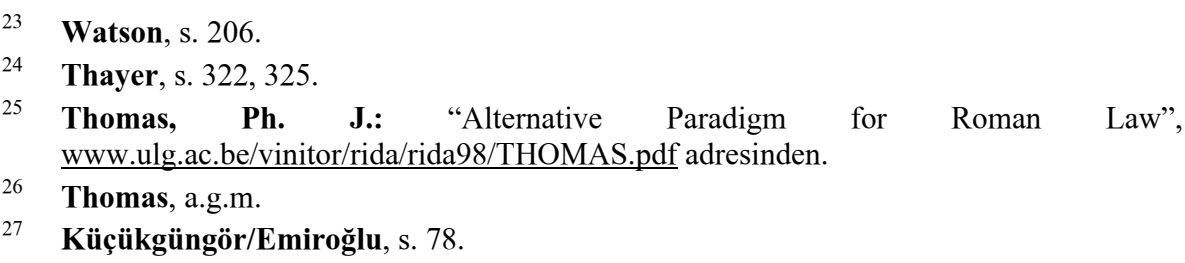




\section{A. FRANSIZ HUKUKUNDA GABİN}

1804 tarihli Frans1z Medeni Kanununun 1674. maddesi "laesio enormis" için oldukça dar bir kapsam sunmaktadır. Buna göre, eğer bir satıcı, taşınmaz satışından 7/12'den daha fazla bir oranda zarar görmüşse, satıș işleminin iptalini isteyebilir. Hatta satıcı, bu sözleşmede bu hakkından feragat etse veya fazla olan değeri bağışladığını belirtse de durum budur ${ }^{28}$. Sözleşmenin iptali için şu dört koşulun bir arada bulunması gerekir: a) Sözleşme, bir satım sözleşmesi olmalı, b) satım, taşınmaz satımı olmalı, c) zarar gören taraf satıcı olmalı ve d) zarar sabit bir oran, yani 7/12'den fazla olmalıdır $^{29}$. Dikkat edileceği üzere, maddede alıcının sömürülmesi durumunda bir öneri ve çözüm getirilmemektedir.

Fransız Hukukunda benzer bir düzenleme, mirasın taksimi sözleşmesinde karşımıza çıkmaktadır. Konuyla ilgili 887. madde hükmüne göre, mirasçılardan biri, miras taksim sözleșmesinde, kendisine düșen miras payının 1/4'ü oranında eksik alması halinde, sözleșmenin feshedilmesini talep edebilir ${ }^{30}$.

Ancak, bu noktada şu ayrımı belirtmeliyiz ki, yaş küçüklüğü durumunda, daha doğru bir ifadeyle, ergin olmayan kişilerle yapılan hukuki işlemlerde, ergin olmayan kişi gabine maruz kalmışsa, mutlak olarak korunur. Hâlbuki ergin kişilerin gabine maruz kalması durumunda, sadece yukarıda ifade edilen sinırlı durumlarda himaye edileceklerdir ${ }^{31}$.

Görüldüğü üzere, Fransız hukukunda gabin, bütün sözleșmelere uygulanabilen genel bir kural değil; kanunun öngördüğü alanlarda uygulama alanı bulabilen sınırlı bir kurum olarak kalmışı̇² ${ }^{32}$.

\section{B. ALMAN HUKUKUNDA GABİN}

1900 tarihli Alman BGB m. 138 konuyu daha farklı bir şekilde düzenlemiştir. Buna göre, ahlaka aykırı olan hukuki işlemler hükümsüzdür. Ayrıca, bir şahsın, ihtiyaç durumundan (müzayaka), deneyimsizliğini, düşüncesizliğini sömürmek suretiyle ve yapılan işlemler arasında açık bir oransızlık varsa ve diğer taraf bundan menfaat elde etmişse, sözleşme hükümsüzdü. ${ }^{33}$

8 Schwarz, s. 348; Buz, Vedat: "Gabin Halinde Edimler Arasındaki Aşırı Oransızlığın Giderilerek Sözleşmenin Ayakta Tutulması”, Batider, Yı1:1998, s. 58; Watson, s. 201.

Watson, s. 201.

30 Ayık, İsmail Hakkı: “Gabinin Mahiyeti ve Unsurları”, Adalet Dergisi, Y11:1952, Say1: 43, s. 243; Buz: s. 58, dipnot 19.

31 Ayık, s. 243.

32 Küçükgüngör/Emiroğlu, s. 84.

33 Watson, s. 201. 
Burada zarara uğrayan taraf için a) her türlü hukuki işlemler için, b) adaletsizlik için tam bir oran gerekmemesine rağmen, işlemde açı/aşikâr bir oransızlığın olduğu durumlarda, fakat c) avantaj sağlayan tarafindan bir aldatma veya sömürme olduğu zaman, dava hakk1 mevcuttur ${ }^{34}$.

Türk-İsviçre hukukundan farklı olarak gabinin varlığı halinde, sözleşme iptal edilebilir olmayıp, mutlak hükümsüzlük yaptırımına bağlanmışıı ${ }^{35}$.

\section{AVUSTURYA HUKUKUNDA GABİN}

Fransiz hukukuna nazaran ve Alman hukukunun aksine, "laesio enormis" konusunda Avusturya hukuku, Roma hukukunun etkisinde daha çok kalmıştır ${ }^{36}$. Avusturya Medeni Kanununun 934. paragrafına göre, karşılıklı sözleşmelerde, taraflardan birinin diğer tarafa verdiğinin yarısından azını alması durumunda, az alan taraf sözleşmeyi sona erdirmek suretiyle eski hale iade talep edebilmekteydi. Sözleşmenin bu şekilde sona ermesi, hukukumuzdan farklı olarak, yenilik doğurucu bir hakkın kullanılması ile değil, mahkeme kararı üzerine gerçekleşebilir. Edimler arasındaki oransızlık sebebiyle menfaat elde eden taraf, aradaki fark1 ödemek suretiyle sözleşmenin feshini önleyebilirdi. ${ }^{37}$ Gabinin varlığ 1 için, edimler arasında "yarıdan az olma" şartı yeterli olup, diğer tarafın "özel durumundan yararlanma" şartı aranmamaktadır ${ }^{38}$.

\section{D. İNGÍLIZZ HUKUKUNDA GABİN}

İngiliz Hukuku bakımından gabin, Kita Avrupa's1 sistemlerinde tanımlanan gabinden daha farklıdır. Bu hukuk sisteminde, gabine tam olarak karşılık gelmeyen, "undue influence" kavramı kullanılmaktadır. $\mathrm{Bu}$ kavramın ifade ettiği husus, bizim anladığımız anlamda gabin ile tam olarak

34 Watson, s. 201; aynı kaynaktan beslenen bu iki hukuk sistemindeki bu farklı yaklaşımlara ilişkin olarak WATSON, şu soruları sormaktadır: "Taşınmaz satıcılarını korumayı ve zararın sabit bir oran olmasını gerektiren bir talep Fransız ruhunda derin bir şekilde kökleşmiş miydi? Burada meşhur Fransız köylüsüne ait taşınmaz hırsı ile Fransız kesinlik sevgisinin bir yansıması mı vardır? Bunun aksine, Alman kuralı, adalete felsefi bir yaklaşımın genellemesini gösteren, kötü bir davranışa cevap ve çare olarak romantik bir bağ mı kurmaktadır? Veya ekonomik terimler arasındaki farkı mı görmekteyiz? 1804 Fransa'sının hâla bir tarım toplumu; 1900 Almanya'sının endüstriyel ve ticarî gücünün bir hamlesini mi? Eğer öyleyse, her iki kanunun koşullarındaki değişmeyişin gerçeği nedir? ...Hepimizin bildiği üzere, genelde Roma Hukuku, Alman ve Fransız modern hukuklarının şekillenmesine önemli bir etkide bulunmuştur. İki kanunda verilen farklı hükümler, bir hukuk veya ikisi için, yerel koşullar veya ulusal gelenek hukukları veya ulusal hislerin Roma hukukuna olan bağlılığ bir kenara koyduğunu mu farz etmeliyiz?”; WATSON, bu son soruya kısaca hayır demektedir. Diğer sorulara da aslında ilginç bir yöntemle, cevabını da yine soru tarzında vermiştir (Watson, s. 201-202).

5 Küçükgüngör/Emiroğlu, s. 85.

Küçükgüngör/Emiroğlu, s. 83.

7 Buz, s. 57.

38 Küçükgüngör/Emiroğlu, s. 83. 
örtüşmemektedir. Nitekim ANSON, konuya ilişkin incelemesinde, bu kavramı ikrah (duress) ile aynı başlık altında incelemiştir ${ }^{39}$. "Undue" kavramı "haksız/yersiz/aşırı"lık, "influence" ise, "nüfuz/etki" anlamına gelmektedir. Dolayısıyla, bu kavramın "haksız nüfuz kullanımı" olarak dilimize çevrilmesi mümkündür.

İngiliz Hukukunda "undue influence" kavramı, ikrah olmaksızın, ahlak dişı (improper) bir baskı altında yapılan sözleşmelerden kurtulmayı sağlayan equitable bir doktrini ifade eder. Mahkemeler, haksız bir menfaat elde etme amaciyla, bir tarafin sömürüldüğü veya suiistimal edildiği durumlarda hadiseye müdahale edebileceklerdir. Bu yaklaşımın temelinde, kamu düzeni kapsamında, sözleşmelerde hakkaniyet unsurunun korunmasına verilen önem vardır ${ }^{40}$.

Haksız nüfuz kullanımı iki kategoride ele alınmaktadır: Birinci kategoride "gerçek haksız nüfuz kullanımı" (actual undue influence), diğerinde ise, "farazî haksız nüfuz kullanımı" (presumed undue influence) vardır. Gerçek haksız nüfuz kullanımında, bir tarafın diğer tarafa uyguladığı gerçek bir nüfuz söz konusu iken; farazî haksız nüfuz kullanımında ise, taraflar arasındaki inanç ve güven ilişkisinden kaynaklanan haksız nüfuz kullanımı ifade edilmektedir. ${ }^{41}$

Gerçek haksız nüfuz kullanımı davalarında iddia şudur: Davacının zararına gerçek bir nüfuz kullanımı sebep olmuş ve sözleşmeyi kabul etmesi için gerçek bir nüfuz kullanımı söz konusu olmuştur. Nitekim 1993 yılında, Lordlar Kamarası CIBC Mortgages plc v Pitt davasını böyle bir dava olarak ele almıştı. Bu davada, davalı hisse senetleri için aldığı ödünç paraya teminat olmak üzere, hiç istemediği halde, ailesine ait evi ipotek ettirmek zorunda bırakılmıştı. Bunu temin için, devamlı bir baskı kampanyası yapılmış ve iradesi hilâfına ikna edilmişti. Bu konuda önemli bir dava, 1985 tarihli National Westminster Bank plc $v$ Morgan davasıdır. Bu dava ile ilgili kararda, açık bir zararın varlığ 1 şart olarak koşulmuştur. Daha önemlisi, gerçek haksız nüfuz kullanımı davalarının da bir çeşit hile olduğu ve diğer hileye maruz kalanlar gibi sözleşme ile bağlı kalmayacakları kabul edildi. Bu kategoriye giren davalarda davac1, sözleşmeden kaynaklanan herhangi bir özel ilişkiyi yada bariz bir zarara uğradığını ispat zorunda değil, fakat özgür iradesinin bir başkası tarafından baskılandığını ispat etmelidir ${ }^{42}$.

Farazî haksız nüfuz kullanımı davaları kendi içinde iki gruba ayrılır:

a) Daima Bir Karine Doğuran İlişkiler: Hukukun özel olarak ele

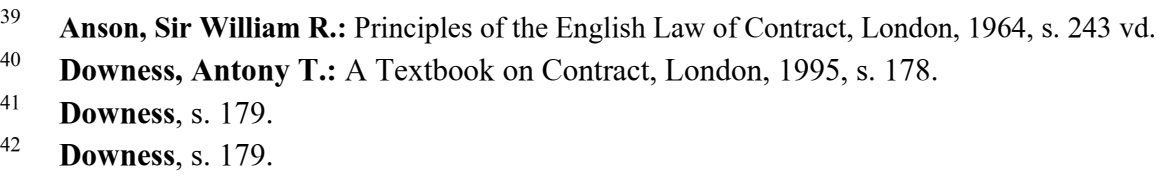


aldığı öyle ilişkiler vardır ki, bunlar her zaman inanç ve güven unsurunu içerirler ve bu sebeple haksız nüfuz kullanımı konusunda, daima bir karine bunlar için geçerlidir. Örneğin, avukat ve müvekkil, doktor ve hasta, annebaba ve çocuk arasındaki ilişkiler böyledir. Fakat karı ve koca arasında, böyle bir karinenin varlığı kabul edilmemiştir.

b) Fiilî (De Facto) Güven ve İnanç Ilişskileri:

Burada, davacının doğrudan haksız nüfuz kullanımı karinesine dayanma imkânı mevcut değilse de, davalı ile aralarındaki ilişkinin, bir güven ve inanç ilişkisi olduğunu gösterme imkânı vardır. Banka ile müşterisi arasındaki ilişki, bu tür ilişkiye örnektir ${ }^{43}$.

Eşler arasındaki ilişkinin bu kapsamda mütalaa edilmesi yeni bir yaklaşımdır. Özellikle kadının, tüm finansal konularda eşine itimat ettiği ve onun önerileri doğrultusunda hareket ettiği davalarda, davacının gerçek haksız nüfuz kullanımı davalarındaki gibi bir ispat yükü olmaksızın, güven ve inanç ilişkisini kanıtlaması yeterli sayılacaktır ${ }^{44}$.

Lord Dennig, 1975 yılında bir temyiz incelemesi esnasında, haksiz nüfuz kullanımının bağımsız bir doktrin olarak değil, taraflar arasında eşit olmayan sözleşme gücünün suiistimali olan ve kapsamlı bir hakkaniyet yetkisinin bir parçası olduğu şeklinde bir yaklaşım sergilemişti. Fakat onun bu yaklaşımı, temyiz mahkemesi üyelerinin çoğunluğunun muhalefeti ile karşılaşmış ve mevcut dava, geleneksel yaklaşım çerçevesinde karara bağlanmıştı. Bu yaklaşım önemliydi. Zira Lord Dennig'in bu yaklaşımı, haksız nüfuz kullanımına ilişkin geleneksel yaklaşımın kapsamı genişletmeye yönelikti ${ }^{45}$.

Bu konuda son olarak şuna işaret edelim ki, İngiliz Hukukunda, haksız nüfuz kullanımının söz konusu olduğu sözleşmelerde, sözleşme kendiliğinden batıl olmayıp, iptal edilebilir bir karakterdedir ${ }^{46}$. Bir başka

43 Banka ile müşterisi arasında böyle bir ilişkinin olduğu durumda, davacının bariz bir zarara uğraması durumunda ispat yükü haksızlık yaptığı iddia edilen tarafa geçer. Yani bir bakıma ispat yükü yer değiştirir. Bu durumda davalı (banka), muhtemelen davacının sözleşme ilişkisine girmeden önce serbestçe tavsiye aldığını ve şartlardan haberdar edildiğini ispat edecektir. Banka ile müşterisi arasındaki ilişkinin güven ilişkisi değil de, alelâde bir ticaret ilişkisi olduğu durumlarda bile banka, müşterisine doğru bilgi veya tavsiye vermelidir. Aksi takdirde bu onun sorumluluğunu gerektirecektir. Cornish $v$ Midland Bank Ltd, 1985, 3 All ER 513 davas1, Downess, s. 180.

44 Barclays Bank plc v O’Brien, 1993, 4 All ER 417, 424. Hatta bu alanın daha da genişletilerek, aralarında evlilik bağı olmasa bile, duygusal ilişki bulunun kişiler arasında fiili bir güven ve inanç ilişkisinin olabileceği kabul edilmiştir. Massey v Midland Bank plc, 1995, 1 All ER 929 davas1; bkz. Downess, s. 181.

45 Llyoyd Bank ltd v Bundy, 1975, QB 326 davas1; bkz. Downess, s. 181-182.

46 Downess, s. 182. 
anlatımla, zarara uğrayan taraf, sözleşmenin iptalini dava etmelidir. Dikkat edileceği üzere, Hukukumuzda geçerli olan yenilik doğurucu bir hakkın kullanımı da bu sonucu yaratmaya elverişli değildir. Sözleşmenin iptali için mutlaka dava açılması yoluna gidilmelidir.

\section{E. MEKSİKA HUKUKUNDA GABİN}

Meksika Medeni Kanununda gabin, hemen hemen Kita Avrupa'sındaki düzenlemelere paraleldir. Bu kanundaki düzenlemeye göre: "Bir şahıs, diğer tarafin aşırı yoksulluğundan veya tecrübesizliğinden veya aşırı bilgisizliğinden yararlanmak suretiyle, aşırı bir menfaat elde etmişse, tarafların borçları (edimleri) arasında aşırı bir oransızlık mevcut ise, zarara uğrayan tarafin sözleşmeyi iptal etme hakkı vardır. Eğer bu mümkün olmazsa, borcundan adil bir indirim yapılmasını isteyebilir.'

F. ULUSLARARASI TICARİ SÖZLEŞMELERE ILISŞKIN UNIDROIT PRENSIPLERİ VE UNIFORM COMMERCIAL CODE HÜKÜMLERINNDE GABİN

Gabin konusuna, "Uluslararası Ticari Sözleşmelere İlişkin Unidroit Prensipleri”nin 3.10. maddesinde (article 3.10) de yer verilmiştir:

“1) Bir taraf, eğer sözleşmede veya sözleşmenin bir şartında, sözleşme sonuçlandığı zaman, sözleşme veya şartı diğer taraf için aşırı bir menfaat sağlıyorsa, bundan kaçınabilir. Bunun göz önünde tutulabilmesi için, şu diğer faktörlerin bulunması gerekir:

a) Diğer taraf, ilk tarafın bağımlı olmasından, ekonomik zaruretinden veya acil ihtiyaçlarından veya basiretsizliğinden, bilgisizliğinden, pazarlık etme yeteneğinin eksikliğinden haksız bir yarar elde etmesi; ve

b) sözleşmenin niteliği ve amac1

2) Mahkeme, (sözleşmeden) kaçınmaya hakkı olan tarafın talebi üzerine, adil bir anlaşmanın makul ticarî standartlarına uyumlu olması için, sözleşme veya şartını uyarlayabilir.

3) Mahkeme, aynı zamanda, sözleşmeden kaçınmaya hakkı olan tarafin kaçınma bildiriminde bulunması üzerine, diğer tarafin böyle bir bildirim aldıktan hemen sonra ve diğer tarafın buna güvenerek davranmasından önce diğer tarafı bilgilendirmesi şartıyla, sözleşmeyi veya şartını da uyarlayabilir. Madde 3.13(2) hükümleri buna dayanarak uygulanır."

ABD hukukunda, anılan prensip hükümlerine en çok benzeyen hükümler Uniform Commercial Code'un 2-302 kısmındaki düzenlemelerdir. $\mathrm{Bu}$ düzenlemeler, genel olarak, mahkemeleri, sözleşme veya şartlarının

Linzer, Peter: "Validity Under Chapter 3 of the Unidroit Principles of International Commercial Contracts", www.cisg.law.pace.edu/cisg/biblio/Linzer.html adresinden. 
fahiş/vicdansız (unconscionable) olması durumunda, sözleşmenin veya ilgili şartının uygulanmasını iptale yetkili kılmaktadır. Fakat bu hükümler, çok etkili olmasına rağmen, sadece semene ilişkin eşitsizliklerde ve tüketici davalarında uygulanmışt. ${ }^{48}$

Uniform Commercial Code'un aksine, pozitif bir hukuk olmayan ve fakat özel bir organizasyonun hukuku geliştirme yönündeki çabası olan Restatement (2.) da benzer hükümler içermektedir. Unidroit prensipleri ile sözleşme Restatement'leri arasında açık bir paralellik vardır. ${ }^{49}$

Yukarıda da işaret edildiği üzere, sözleşme özgürlüğü ve buna müdahale edilmesi o ülkenin ekonomik sistemiyle ve ideolojisi ile yakından ilgilidir. Nitekim LINZER, Unidroit prensiplerinin, "bağımlılık", "ekonomik zaruret", "acil ihtiyaçlar", "basiretsizlik" ve "tecrübesizlik" gibi kavramlarının genişliği ve belirsizliği sebebiyle, özellikle gelişmekte olan ülkelerin şirketlerine, sözleşmenin onlar için kârlı olmadığ durumlarda başvurabilecekleri bir yol olması ve yine bu belirsiz ve geniş kavramların hukuk davalarına davetiye çıkaracak mahiyette olduğunu ileri sürmektedir. Muhafazakâr Amerikan ticaret hukukçularının bu kurallardan kaygı duyduklarını da ifade etmektedir ${ }^{50}$. Bundan da anlaşılacağ 1 üzere, ilkelere bakış, bakan tarafın konum ve ideolojisi ile yakından ilgilidir. Muhafazakâr ABD hukukçularının ilkelere bu yaklaşımına karşılık, gelişmekte olan ülkelerin hukukçuları ise, muhtemelen sözleşme adaletinin garantisi gözüyle bakacaklardır.

\section{G. TÜRK-İSVIÇRE HUKUKUNDA GABIN}

Gabin, iki tarafa borç yükleyen sözleşmelerde, edimler arasında açık bir oransızlık var ise ve bu, zarara uğrayan tarafın ekonomik sıkıntısından veya irade zayıflı̆̆ından ${ }^{51}$ yahut tecrübesizliğinden yararlanmak suretiyle elde edilmesidir.

Bu tanımdan yola çıkarak, gabinin unsurlarını belirlemek mümkündür:

\section{GABININ UNSURLARI}

Gabinden söz edebilmek için genellikle, biri edimler arasındaki açık oransızlığı ifade eden objektif, diğeri kanundaki ifadesiyle, müzayaka, hiffet ve tecrübesizlikten yararlanmayı ifade eden sübjektif iki unsurun varlığının gerekliliğine işaret edilmektedir. Buna karşılık, SAYMEN, unsurlara ilişkin böyle bir tasnifin yanlış olacağını; zira "yararlanma"nın gabine maruz kalan kişinin sübjektif bir yönü olmadığını ve ayrı bir unsur şeklinde

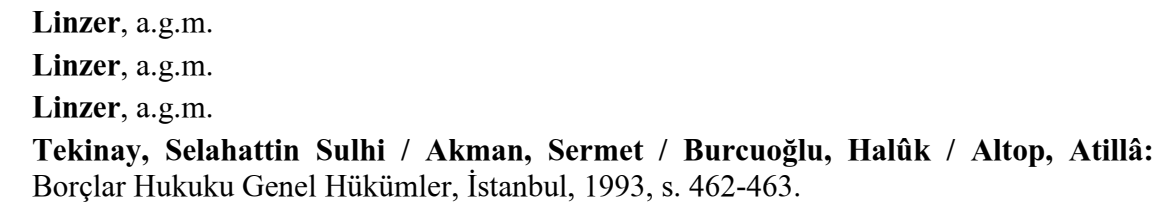


değerlendirilmesi gereğine işaret etmektedir ${ }^{52}$. Oysa, ELBİR'in de işaret ettiği üzere, "yararlanma" tek başına unsur olarak bir anlam ifade etmeyeceği gibi, objektif ve sübjektif unsur arasında bulunmas1 gereken illiyet bağını zayıflatma tehlikesini barındırdığından, iki unsur şeklindeki bir inceleme daha yerinde olacaktır ${ }^{53}$.

Objektif ve sübjektif unsurun birlikte bulunması gerekir. Örneğin, edimler arasında açık bir oransızlığın varlığına karşılık; bu oransızlık, zarara uğrayan tarafin "müzayaka"sından, "hiffet"inden veya "tecrübesiz"liğinden yararlanmak suretiyle oluşturulmamış ise, gabinden bahsedilemez.

\section{a. Objektif Unsur: Edimler Arasında Açık Oransızlık}

Yukarıda da izah ettiğimiz üzere, edimler arasındaki açık oransızlığ ifade eden objektif koşula ilişkin, Roma hukuku \% 50, Avusturya hukuku \% 50'den fazla, Fransız hukuku taşınmaz satışında 7/12, miras taksim sözleşmelerinde $1 / 4$ gibi belirli bir oran belirlemişlerdir. Oysa Alman Hukuku ile Türk-İsviçre Hukukunda böyle sabit bir oran belirlenmemiş, açık oransızlığın tespiti, somut olaya göre hâkimin takdirine bırakılmıştır. $\mathrm{Bu}$ yaklaşım tarzı daha isabetlidir. Zira kesin bir oran belirlenmesi iki açıdan açıklanamaz ve sakınca teşkil eder. Her şeyden önce, Avusturya Hukukunu örnek olarak ele alırsak, \% 51 oransizlığı kabul edip, \%50'yi kabul etmemekte ne gibi bir adalet ölçüsü kullanılmıştır. Adalet, böyle kesin bir çizgiye sahip midir? Kurnaz olan taraf, pek doğal olarak, hukukun bu ince çizgisini bilip, tecrübesizliğinden istifade ettiği şahsı bilerek \% 50 sınırında tutup sömürdüğünde, hukuk düzeni buna kayıtsız mı kalacaktır? Öte yandan, oranlar her koşulda aynı anlamı taşır mı? Sözgelimi 100 YTL değerinde bir radyonun \% 40 düşük fiyatla satın alınması ile 400.000 YTL değerindeki bir taşınmazın \% 40 düşük fiyatla satın alınması aynı anlamı taşır mı? Hiç şüphesiz bu sorulara olumsuz yanıt vermek gerekir. Bu sebepledir ki, kesin bir oran belirlemeyen ve bu konuda hâkime takdir yetkisi tanıan Kanunumuzun sistemi daha yerindedir.

Objektif unsurun varlığı, sözleşmenin kurulduğu tarihe göre belirlenmelidir. Yoksa sonradan piyasa koşullarındaki değişimler sebebiyle bir oransızlık ortaya çıkmışsa, bu dikkate alınmaz ${ }^{54}$.

52 Saymen, Ferit Hakkı: "Gabin-Müzayaka-İstifade Şartı (İçtihat Notu)", İ.H.F.M., Sayı:1-2, Cilt: 13, s. 800; nitekim, SAYMEN, unsurları üçe ayırarak incelemektedir; bkz. Saymen, Ferit Hakkı: Borçlar Hukuku Dersleri, Cilt I, İsmail Akgün Matbaası, 1950, s. 166-169; benzer şekilde ayrıca bkz. Kılıçoğlu, Ahmet M.: Borçlar Hukuku Genel Hükümler, Ankara, 2003, s. 129-130.

53 Elbir, Halid Kemal: “Gabnin Unsurlar1”, İstanbul Barosu Dergisi, Y1l: 1951, s. 195.

54 İnan, Ali Naim: Borçlar Hukuku Genel Hükümler Ders Kitabı, Ankara, 1984, s. 147; Saymen, s. 166-167; Eren, Fikret: Borçlar Hukuku Genel Hükümler, İstanbul, 2003, s. 378. 
Her oransızlık gabin sonucunu doğurmaz. Bunun için, oransızlı̆̆ın Kanunumuzun ifadesiyle "açık" olması gerekir". Bundan kastedilen, oransızlığın işten anlayan herkesin gözüne çarpar nitelikte olmasıdır ${ }^{56}$. Her ne kadar, "orta zekâlı bir kişinin ilk bakışta anlayacağı" gibi bir ölçüden söz edilmiş ise $\mathrm{de}^{57}$, bu ölçü tek başına yeterli olmayacaktır. Bunun için "işten anlamak" gerekir. Çok zeki olmasına rağmen, işten anlamayan bir kişinin, bu oransizlığ fark edememesi gayet normaldir.

Kanunumuzun sisteminde her ne kadar bir oran belirlenmemiş ve hâkime bir takdir yetkisi verilmiş ise de, bu konuda doktrindeki görüşlerin ışığıyla, hâkime takdir yetkisini kullanırken yardımcı olabilecek bazı ölçüler sunmak mümkündür. Örneğin, değerli olmakla birlikte, paraya çevrilmesinde güçlük bulunan mallar bakımından, hâkim daha dikkatli davranmak zorundadır; zira bu gibi mallarda alıcı bir risk üstlenmektedir. Çok kıymetli ve nadir malların gerçek değerini belirlemekteki güçlük dikkate alınmalı, özellikle bu konuda bilirkişi görüşleri daha dikkatli değerlendirilmelidir. Müşterek mülkiyete konu mallar veya ihtilaflı mallar, edimin değerini etkileyeceğinden, bu hususa dikkat edilmelidir ${ }^{58}$. Edimin sadece değeri değil, gelecekte ödemenin sağlamlığı da, bir başka ifadeyle, ifa edilmeme tehlikesi de dikkate alınmalıdır ${ }^{59}$.

Her sözleşmede tarafların kazanç elde etmesi doğal olduğundan ve Borçlar Kanunumuzda sözleşme serbestliği ilke olduğundan, oransızlığın çok aşırı olduğu ve sömürü olarak kabul edilebildiği durumlarda, gabine ilişkin kuralı işletmek gerekir ${ }^{60}$.

\section{b. Sübjektif Unsur}

Gabinde sübjektif unsur, edimler arasındaki oransızlığın, zarar gören kişinin özel durumundan ${ }^{61}$ yararlanılarak elde edilmesidir. Kanunda "müzayaka", "hiffet" ve "tecrübesizlik" olarak adlandırılan bu özel durumlara ilişkin sayma, tahdididir ${ }^{62}$. Bu üç sınıfa girmeyen yararlanma

55 Federal Mahkeme, bir kararında; bir kaza sebebiyle, zarara uğrayan şahsın, tedavi masrafları karşılığında yapılmış feragat sözleşmesindeki feragatin açık bir oransızlık olduğunu kabul etmiştir; bkz. Sungur, Hasan Halis: Gabin, İstanbul, 1953, s. 27.

56 Tunçomağ, Kenan: Borçlar Hukuku Genel Hükümler, I. Cilt, İstanbul, 1972, s. 244; Olgaç, Senai: Hukuk Davalarında Gabin Hata-Hile-İkrah, s. 6; Sungur, s. 23.

57 Bu yönde bkz. İnan, s. 148; Olgaç, s. 6.

58 Tekinay/Akman/Burcuoğlu/Altop, s. 460-461.

59 Oser, H. / Schönenberger, W.: Borçlar Hukuku, (çev. Recai Seçkin), Ankara, 1947, s. 188; Sungur, s. 22.

60 Aybay, Aydın: Borçlar Hukuku Dersleri Genel Bölüm, İstanbul, 1991, s. 49.

61 Eren, s. 379.

62 Tunçomağ, s. 244; Sungur, s. 28; Renda, Nihat - Onursan, Galip: Dördüncü Hukuk Dairesinin Emsal Kararlarıyle- Borçlar Hukuku, Cilt II, Ankara, 1973, s. 702. 
durumları gabine varlık sağlamaz. Aksi takdirde, müesseseyi sözleşme özgürlüğünü anlamsız kılacak boyutta genişletmek riski ile karşı karşıya kalınabilir. Ayrıca, bu üç koşulun birlikte bulunması gerekmez. Bu koşullardan birinin varlığı objektif koşulla birleşmek şartıyla, gabin sebebiyle sözleşmenin iptaline yeter.

Zarar görenin özel durumunu, Kanunumuzun adlandırdığı biçimde şu kısımlara ayırabiliriz:

\section{aa) Zarar Görenin Müzayaka Halinden Yararlanma}

Müzayaka hali, kişinin içinde bulunduğu darda kalma halini ve çoğunluklu ekonomik sıkıntısını ifade eder. Müzayaka hali ile fakirlik karıştırılmamalıdır. Zengin olmasına rağmen, kişi, örneğin nakit sıkıntısı sebebiyle, müzayaka halinde olabilir ${ }^{63}$.

Müzayaka halindeki kişi, kendisinin veya yakınlarından birinin maddi veya manevî bütünlügünü veya sosyal durumun tehdit eden bir zararın varlığından korkmaktadır ${ }^{64}$. Bu itibarla, maddi/ekonomik olabileceği gibi, manevî/kişisel de olabilir ${ }^{65}$. Manevî/kişisel müzayakanın başlıca nedenleri, yaşlılık ve yalnızlıktır ${ }^{66}$.

Müzayaka halinde bulunmada, zarar gören kişinin kusurundan doğmuş olması veya olmasından korkulan zararın yerinde yahut yersiz olması sonucu değiştirmez ${ }^{67}$.

Bir kişi, karşı tarafın müzayaka durumunu bizzat yaratmış ve onun bu durumuna son verme borcu ile yükümlü bulunmuş ise, müzayaka halinden yararlanma, aynı zamanda bir ikrah teşkil eder ${ }^{68}$.

\section{bb) Zarar Görenin Hiffetinden (Hafifliğinden) Yararlanma}

Hiffet, özen göstermeme ve düşüncesizlik halini ifade eden ${ }^{69}$ bir irade zayıflığıdır ${ }^{70}$. Ancak, burada söz konusu olan irade zayıflığı genel bir irade zayıflığı olmayıp, somut bir olay veya işlem karşısındaki irade zayıflığıdır ${ }^{71}$.

$\mathrm{Bu}$ özellikteki kişiler, yapacağı hukukî işleme çabuk karar vermekte, sonuçlarını düşünmemekte ve belli bir olayda ciddi düşünmeyi bir tarafa

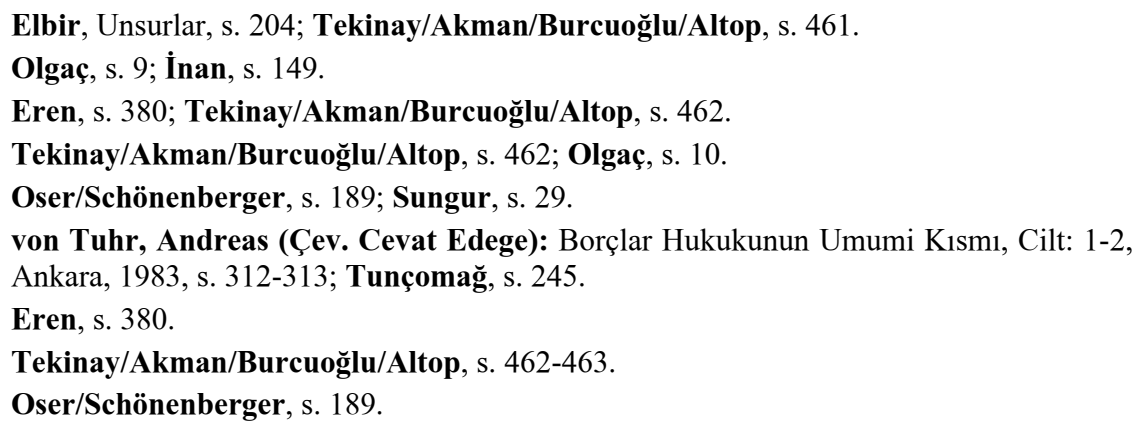


bırakmakta ve bu suretle sömürülmeye açık bulunmaktadırlar ${ }^{72}$. Bu durumun daha ziyade çok genç ve çok yaşlilarda görülen bir ruh hali olduğu ifade edilmektedir ${ }^{73}$. Şunu vurgulamak gerekir ki, hiffet; temyiz kudretinin yokluğu şeklinde anlaşılmamalıdır ${ }^{74}$. Gösterilen irade zayıflı̆g somut ve belli bir olaya ilişkindir. Temyiz kudretinden yoksun olmamakla birlikte, akıl ve zekâ yönünden yeteri kadar gelişmemiş kişilere de, bu hüküm tatbik edilir ${ }^{75}$.

Kişinin hiffetinden yararlanma, çoğu durumda hile ile birleşir ${ }^{76}$. Ancak, bunun için somut olayda, gabin ile hilenin çelişir halde bulunmaması gerekir.

\section{cc) Zarar Görenin Tecrübesizliğinden Yararlanma}

Tecrübesizlik, zarar gören kişinin genel hayat ve iş hayatındaki bilgi eksikliğini ifade eder ${ }^{77}$. Hiffet bir irade zayıflığ 1 iken, tecrübesizlik bir bilgi zayıflığıdır ${ }^{78}$. Hiffet ile hareket eden, gerçeği görmek istemez, tecrübesiz ise göremez ${ }^{79}$.

Tecrübesizliğin varlığ 1 araştırılırken, tarafların kültürel, sosyal ve eğitim koşulları göz önünde bulundurulmalı ve bu durumda, eğitimli kişiler ile eğitimsiz kişiler arasında fark gözetilmelidir ${ }^{80}$. Ancak, günümüzdeki teknolojik gelişmelerin hızı da gözden uzak tutulmamalıdır. Zira bu baş döndürücü gelişme, eğitimli kişileri bile zamanla tecrübesiz duruma getirebilmektedir $^{81}$.

\section{GABİNLİ SÖZLEŞMENIN HÜKMÜ}

Yukarıda da açıkladığımız üzere, Alman Hukukunda gabinin varlığı

\section{Olgaç, s. 8 .}

73 Tekinay/Akman/Burcuoğlu/Altop, s. 462-463; İNAN, yaşlı bir erkeğin genç ve güzel bir kadına tutulmak suretiyle yaptığı sözleşmeleri, bu konuda örnek olarak vermektedir; bkz. İnan, s. 150.

74 INAN, kural olmamakla birlikte, bu gibi (hiffetinden istifade edilen) kișilerin, çoğunlukla hacir altına alındığını ifade etmektedir, bkz. İnan, s. 150.

75 von Tuhr, s. 312.

76 von Tuhr, s. 312; Tunçomağ, s. 245; Renda-Onursan, s. 705.

Tekinay/Akman/Burcuoğlu/Altop, s. 463; Eren, s. 380.

Tekinay/Akman/Burcuoğlu/Altop, s. 463.

Elbir, Unsurlar, s. 206; Olgaç, s. 7.

Kılıçoğlu, s. 129.

81 Elbir, Unsurlar, s. 207; Olgaç, s. 7-8; Eren, s. 380; bu unsur, Türk Ticaret Kanununun 20. maddesi sebebiyle, tacirler hakkında uygulanamaz. Daha doğru bir ifadeyle, tacirler, faaliyet gösterdikleri ticari alanda tecrübesizliğinden yararlanılmış olduğunu ileri sürerek, yaptıkları bir sözleşmenin gabin sebebiyle iptalini isteyemezler. Zira tacirler, ticaretine ait bütün faaliyetlerinde basiretli bir tacir gibi hareket etmek mecburiyetindedirler; bkz. Kılıçoğlu, s. 129. 
durumunda sözleşme bâtıl sayılmakta idi. Dolayısıyla, belli bir zamanın geçmesiyle sözleşme geçerlik kazanmayacaktır. Avusturya Hukukunda ise, sözleşme batıl olmamakla birlikte, feshedilebilir bir niteliktedir. Ancak, sözleşmenin feshi için yargı kararına ihtiyaç vardır. Benzer şekilde, İngiliz Hukukunda da sözleşme iptal edilebilir bir hükme tâbidir. Burada da, dava açma yoluyla sözleşmenin iptali istenebilir. Fransız Hukukunda da sözleşme iptal edilebilir durumdadir.

Türk-İsviçre Hukukunda da, gabinle sakatlanmış bir sözleşme, iptal edilebilir olup, bâtıl değildir. Dolayısıyla, burada bir "askıda hükümsüzlük" durumu söz konusudur ${ }^{82}$. Sözleşmenin hüküm ifade edip etmemesi, zarar görenin iradesine bırakılmıştır. Zarar gören dilerse, sözleşme ile bağlı olmadığını tek taraflı bir irade beyanı ile karşı tarafa bildirip, askı durumunu sonu erdirebileceği gibi, dilerse açık veya örtülü irade beyanıyla, sözleşme ile bağ lılığını kabul etmek suretiyle de askı durumunu sona erdirebilir.

Türk-İsviçre Hukuku gabin sebebiyle sözleşmenin iptalinde, diğer hukuklardan farklı olarak "beyan sistemi"ni kabul etmiştir ${ }^{83}$. Gabine maruz kalan taraf, dava açmaya gerek olmaksızın, sözleşme ile bağlı olmadığını beyan etmek suretiyle, sözleşmeyi iptal edebilecektir. Bu irade beyanı, Kanunda açıkça belirlenmemiş olduğu için, herhangi bir şekle tâbi değildir. Ancak, ispat hukuku bakımından, yazılı olmasında fayda vardır. Bu beyan, bozucu yenilik doğuran bir haktır ${ }^{84}$. Sözleşmenin devamını istiyorsa, karşı tarafin dava açması gerekecektir ${ }^{85}$.

Sözleşmeyi iptal yetkisi, zarar gören, bir başka anlatımla sömürülen tarafa aittir $^{86}$. Zarar gören taraftan kastımız, sözleşmenin kurulduğu anda zarar gören kişidir. Yoksa zaman içinde ekonomik ve sosyal durumdaki değişiklikler sebebiyle, zarar gören tarafin değişmesi mümkündür. Örneğin, İstanbul'un Avcılar ilçesinde, Nisan 1999 tarihinde 20.000 YTL değerindeki bir taşınmazı 10.000 YTL fiyatla satın alındığını düşünelim. Depremden sonra, özellikle yeni bir deprem beklentisi sebebiyle, bu bölgedeki taşınmazlarda \% 70'i aşan değer kayıpları ortaya çıkmıştı. Bu durumda, Nisan ayı itibariyle zarar gören satıcı iken, depremden sonra, alıcı zarar gören duruma düşmüştür.

Kanun, sözleşmeyi iptal konusunda, zarar görene bir yıllık süre tanımıştır; bu süre hak düşürücü süredir ve bu sebeple, hâkim tarafindan

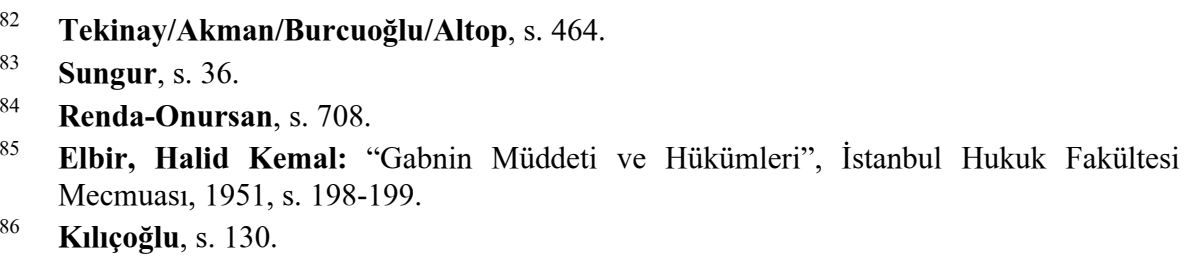


resen nazara alınır ${ }^{87}$. Sürenin başlangıcı, -hata, hile ve ikrahtan farklı olaraköğrenme tarihi değil, sözleşmenin kurulduğu tarihtir ${ }^{88}$. Ancak, yukarıda da belirttiğimiz üzere, gabin bazen hile veya ikrah ile birleşebilir. Bu durumda, daha elverişli olan B.K.'nun 31. maddesi hükmü uygulanmalıdır ${ }^{89}$. Bir yıllık sürenin, zarara uğrayan tarafın zararı "bilme"si nazara alındığında, müzayaka için yeterli bir süre olmasına rağmen, hiffet ve tecrübesizlik durumunda ise, çok yetersiz olduğu, haklı olarak, ifade edilmiştir ${ }^{90}$.

Gabin halinde, edimler arasındaki oransızlığın giderilerek sözleşmenin ayakta tutulmasının mümkün olup olmadığı, tartışmalıdır. Doktrinde genel olarak, zarara uğrayan tarafa, sözleşmenin iptali hakkının yanı sıra sözleşmeyi hükümsüzlükten kurtarmak için, hâkimden oransızlığın giderilmesi, hakkaniyete uygun bir değişiklik yapılmasını talep etme imkânı tanınmasının yerinde olacağı ifade edilmektedir ${ }^{91}$. Buna karşılık, bu tür sözleşmelerin ya zarara uğrayanın iradesi ile geçerli sayılması veya yine onun iradesi ile hükümsüz sayılması gerektiği, bunun dışında bir yolun caiz olmadığı ileri sürülmüştür. Özellikle, hâkimin, mevcut mevzuat karşısında böyle bir yetkisinin bulunmadiğı, yorum yoluyla da bu sonuca ulaşılamayacağı, zira "yararlanma" unsurundaki ahlaka aykırıllı̆ın buna engel teşkil ettiği, ifade edilmektedir. Öte yandan, sömüren tarafin, edimler arasındaki farkı ödemeyi teklif etmek suretiyle, sözleşmeyi kurtarmasının da mümkün olmadığı ifade edilmektedir ${ }^{92}$.

Gabin sebebiyle sözleşme feshedildiği takdirde, şayet taraflar edimlerini ifa etmemiş iseler, sorun yoktur. Bu takdirde, taraflar feshedilmiş bu sözleşme sebebiyle, borçlarını ifa etmeyeceklerdir. Şayet, taraflar edimlerini ifa etmişseler, bu takdirde, verdiklerini sebepsiz zenginleşme veya istihkak davası ile geri isteyebilirler ${ }^{93}$.

Gabin sebebiyle sözleşmenin feshedilmesi durumunda, sömürülen tarafin tazminat talep edip edemeyeceğine ilişkin 21. maddede bir açıklık bulunmamaktadır. Çoğunlukla kabul edilen görüşe göre, tazminat talebi mümkündür ve bunun hukuki niteliği de, sözleşme müzakerelerinde bulunması gereken iyiniyet kurallarına aykırılık sebebiyle, sömürülen taraf

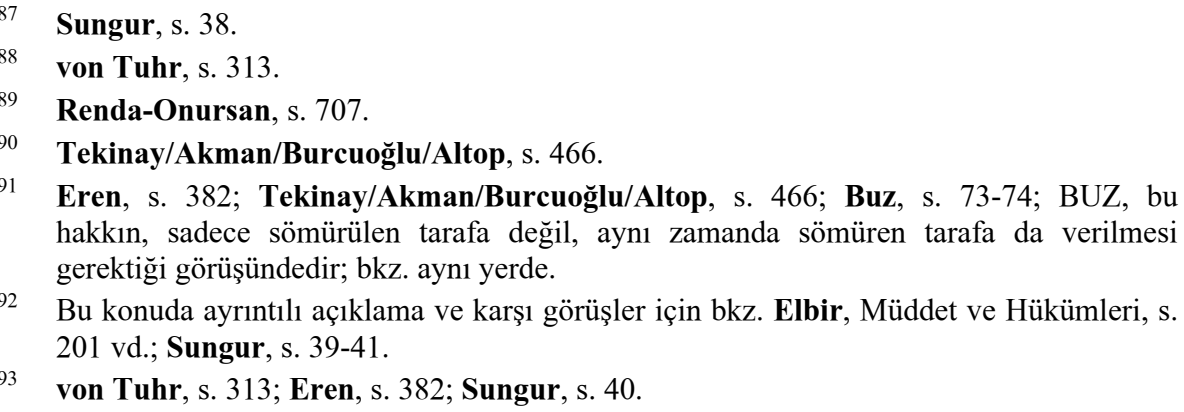


zarara uğramışsa, bu zarar tazmin edilmelidir ve tazminatın miktarı da menfi zararla sinırlıdır ${ }^{94}$.

\section{SONUÇ}

İki taraf borç yükleyen sözleşmelerde, edimler arasındaki oransızlığın giderilmesi konusunda, yani bu tür sözleşmelere hukuk düzenince yaptırım uygulanması sistemli olarak ilk defa Roma hukukunda gündeme gelmiştir. Diocletianus veya Iustinianus dönemine mi ait olduğu kesinlikle belirlenemeyen iki emirname, Ortaçağ commentator'larının adlandırması ile laesio enormis, günümüzde de uygulama alanı bulmuş ve Roma hukukunun ne denli güncel ve ileri bir düşünüşün eseri olduğunu bir kez daha ortaya koymuştur.

İki tarafa borç yükleyen sözleşmelerde, edimler arasındaki aşırı ve göze çarpan oransızlığın, diğer tarafın, tecrübesizliği, darda kalma hali veya irade zayıflığından yararlanmak suretiyle sömürme halini aldığı zaman, buna hukuk düzeninin müdahale edip etmeyeceği, o ülkenin ekonomik ve sosyal düzeni ile ilgilidir. Yukarıda da gördüğümüz üzere, bazı hukuk sistemleri, bu tür durumları sözleşme özgürlüğ̈̈ çerçevesinde ele almışlar ve bu konuda zarara uğrayan tarafın zararının giderilmesine yönelik hükümler getirmekten kaçınmışlardır. Buna karşılık, bazı hukuk sistemleri de, bu tür sözleşmelere müdahale gereği duymuşlardır. Fransa örneğinde olduğu gibi, bazı hukuk sistemleri de, sadece sinırlı konularda bu alana müdahale etmişlerdir.

Günümüz koşullarında, özellikle ülkemiz gibi, sosyal devlet ilkesini benimsemiş ülkelerde, sözleşmede güçlü konumda olanlara karşı zayıf tarafin korunması devletin/hukukun bir ödevidir. THOMAS'in da işaret ettiği gibi, salt sözleşme özgürlüğü, kavram olarak endüstriyel kapitalizm ile siyam ikizleri gibidir. Oysa bilinir ki, salt özgürlükten söz edebilmek için; her şeyden önce taraflar arasında güç dengesinin bulunması gerekir. Eğer böyle bir dengeden söz edilemiyorsa, dengeyi hukuk düzeninin sağlaması, sosyal adaletin gereğidir. Nitekim hukuk düzenimiz de, bu yönde tavır almış ve karşılıklı sözleşmelerde sömürülen tarafın korunmasına yönelik, B.K.'nun 21. maddesi hükmünü sevk etmiştir.

Kanunumuzun düzenlemesi incelendiğinde, örneğin Fransa'dan farklı olarak, gabin; her türlü sözleşmeye uygulanabilecek nitelikte bir kuraldır. $\mathrm{Bu}$ yönüyle de daha isabetlidir.

Almanya'dan farklı olarak, gabinli sözleşmenin hükmü butlan değil, iptal edilebilirliktir. $\mathrm{Bu}$ yönüyle de, kanunumuzun çözüm tarzı daha isabetlidir. SCHWARZ'ın da belirttiği gibi, gabine rağmen, zarara uğrayan taraf sözleşmenin devamını istiyorsa, bunu bâtıl saymakta bir kamu yararı olamaz.

94 von Tuhr, s. 313; Eren, s. 382; Sungur, s. 41. 
Avusturya, Fransa gibi ülkelerden farklı olarak, gabinin objektif unsuru olan edimler arasındaki aşırı oransızlığın belirlenmesinde hâkime takdir yetkisi tanıyan kanunumuz sistemi daha yerindedir. Gerçekten de, adaletin böyle matematiksel bir çizgisinin kabul edilmesi isabetli olmayacaktır.

Gabin ile sakat sözleşmelerin, edimler arasındaki oransızlı̆̆ın giderilerek ayakta tutulması konusunda, bunun mümkün olamayacağını savunanların görüşüne katılmaktayız. Zira bu konuda eğer yetki, alıcıya veya satıcıya verilirse, yani tek tarafın talebi bu konuda dikkate alınırsa, diğer tarafın bundan hoşnut olmama riski ortaya çıkacak ve aslında sözleşme özgürlüğü o zaman ihlal edilmiş olacaktır. Bunun yanı sıra, bu konuda pozitif bir dayanak da bulmak mümkün değildir. Şöyle ki, kanun koyucu bu konuda hâkime müdahale yetkisi tanımamıştır. Hâkim, ya sözleşmenin geçerliliğine ya da geçersizliğine karar vermek durumundadır. Bunun dışındaki bir yetkinin, kanuni dayanağı yoktur. Öte yandan, iki tarafin üzerinde uzlaşmaları halinde hâkimin yetkisinin olabileceği veya bu durumun caiz görülebileceği düşünülürse, o takdirde, iki tarafın üzerinde uzlaştıkları husus artık eski sözleşme olmayıp, yeni bir sözleşme niteliğindedir ki, bunun için hâkimin müdahalesine de ihtiyaç yoktur.

Hak düşürücü süreye ilişkin eleştiri, belki kanunumuzun düzenlemesine getirilebilecek en önemli eleştiridir. Gerçekten de, "akdin inikadı"ndan itibaren işleyecek bir yıllık hak düşürücü süre, TEKİNAY'ın da belirttiği gibi, "müzayaka" hali için yeterli ise de, "tecrübesizlik" veya "hiffet" hali için yetersizdir. 


\section{KAYNAKÇA}

ANSON, Sir William R.: Principles of the English Law of Contract, London, 1964.

AYBAY, Aydın: Borçlar Hukuku Dersleri Genel Bölüm, İstanbul, 1991.

AYIK, İsmail Hakkı: "Gabinin Mahiyeti ve Unsurları”, Adalet Dergisi, Yı1:1952, Say1: 43.

BUZ, Vedat:"Gabin Halinde Edimler Arasındaki Aşırı Oransızlı̆̆ın Giderilerek Sözleşmenin Ayakta Tutulması”, Batider, Yı1:1998.

DOWNESS, Antony T.: A Textbook on Contract, London, 1995.

ELBİR, Halid Kemal: “Gabnin Müddeti ve Hükümleri”, İstanbul Hukuk Fakültesi Mecmuası, 1951.

ELBİR, Halid Kemal: “Gabnin Unsurları”, İstanbul Barosu Dergisi, Yı1: 1951.

EREN, Fikret: Borçlar Hukuku Genel Hükümler, İstanbul, 2003.

INAN, Ali Naim: Borçlar Hukuku Genel Hükümler Ders Kitabı, Ankara, 1984.

KILIÇOĞLU, Ahmet M.: Borçlar Hukuku Genel Hükümler, Ankara, 2003.

KÜÇÜKGÜNGÖR, Erkan / EMIROĞLU, Haluk: "Roma Hukukunda ve Bazı Çağdaş Hukuk Düzenlerinde Laesio Enormis", A.Ü.H.F.D., Cilt: 53, Sayı: 51.

LINZER, Peter: "Validity Under Chapter 3 of the Unidroit Principles of International Commercial Contracts", www.cisg.law.pace.edu/cisg/biblio/Linzer.html adresinden.

OLGAÇ, Senai: Hukuk Davalarında Gabin Hata-Hile-İkrah.

OSER, H./SCHÖNENBERGER, W. (Çev. Recai SEÇKIN): Borçlar Hukuku, Ankara, 1947.

RADO, Türkan: Roma Hukuku Dersleri-Borçlar Hukuku, İstanbul, 1982.

RENDA, Nihat-ONURSAN, Galip: Dördüncü Hukuk Dairesinin Emsal Kararlarıle- Borçlar Hukuku Cilt II, Ankara, 1973.

SAYMEN, Ferit Hakkı: "Gabin-Müzayaka-İstifade Şartı (İçihat Notu)", İ.H.F.M., Sayı:1-2, Cilt: 13.

SAYMEN, Ferit Hakkı: Borçlar Hukuku Dersleri, Cilt I, İsmail Akgün Matbaası, 1950.

SCHWARZ, Andreas B. (çev. Bülent DAVRAN): Borçlar Hukuku Dersleri, I. Cilt, İstanbul, 1948.

SUNGUR, Hasan Halis: Gabin, İstanbul, 1953.

TAHİROĞLU, Bülent: Roma Borçlar Hukuku, İstanbul, 2000.

TEKINAY, Selahattin Sulhi / AKMAN, Sermet / BURCUOĞLU, Halûk / ALTOP, Atillâ: Borçlar Hukuku Genel Hükümler, İstanbul, 1993. 
THAYER, J.B.: "Laesio Enormis" www.heinonline.org/HOL/Page? handle $=$ hein.journals $/$ kentlj25\&size $=2 \&$ collection $=$ journals $\& i d=331$ adresinden.

THOMAS, PH.J.: “Alternative Paradigm for Roman Law", www.ulg.ac.be/vinitor/rida/rida98/THOMAS.pdf adresinden

TUNÇOMAĞ, Kenan: Borçlar Hukuku Genel Hükümler, I. Cilt, İstanbul, 1972.

UMUR, Ziya: Roma Hukuku Ders Notları, İstanbul, 1987.

UMUR, Ziya: Roma Hukuku Lügatı, İstanbul, 1983.

VON TUHR, Andreas (Çev. Cevat EDEGE): Borçlar Hukukunun Umumi Kısmı, Cilt: 1-2, Ankara, 1983.

WATSON, Alan: Roman Law\&Comparative Law, University Atina-Londra, 1991. 